\title{
The Existence of the Nahdlatul Ulama Party in the Guided Democracy Era
}

\author{
Rina Andriani Hidayat \\ LAIN Salatiga \\ rina.aniandri@gmail.com
}

\begin{abstract}
Abstrak
Tulisan ini dilatarbelakangi oleh keberhasilan Nahdlatul Ulama menjadi sebuah partai politik Islam terbesar pada masa Demokrasi Terpimpin. Selain itu, pada masa ini, PNU memegang peranan penting dalam kancah politik nasional sebagai salah satu komponen utama politik "Nasakom" yang diusung oleh Presiden Soekarno dari kalangan beragama. Bahkan PNU berhak mempunyai wakil di semua komisi dan organisasi pemerintahan. Pokok permasalahan dalam tulisan ini adalah mengapa PNU berhasil mempertahankan eksistensinya sebagai partai politik Islam dan menjadi salah satu komponen utama politik "Nasakom" pada masa Demokrasi Terpimpin? Berdasarkan permasalahan tersebut maka dirumuskan beberapa pertanyaan penelitian sebagai berikut: Mengapa NU berubah menjadi sebuah partai politik? Bagaimana kebijakan politik Soekarno masa Demokrasi Terpimpin? Bagaimana sikap politik PNU pada masa Demokrasi Terpimpin? Eksistensi politik PNU pada masa Demokrasi Terpimpin ditulis menggunakan metode sejarah dengan pendekatan behavioristik. Adapun lingkup spasial dan temporal penelitian pemerintahan Soekarno pada masa Demokrasi Terpimpin (1959-1965). Hasil Penelitian menunjukkan bahwa pendirian PNU dilatarbelakangi oleh sikap ketidakpuasan PNU terhadap kebijakan politik Partai Masyumi. Keikutseertaan PNU dalam Pemilu 1955, menjadikan PNU sebagai partai politik terbesar ke-3 setelah PNI dan Partai Masyumi. Pada masa Demokrasi Terpimpin, PNU berusaha mempertahankan eksistensinya dengan mendukung setiap kebijakan politik Soekarno melalui dukungan yang didasari oleh prinsip-prinsip kaidah ushul fikih, yaitu kebijaksanaan, keluwesan dan moderatisme. Sekalipun dalam proses pengambilan keputusan seringkali terjadi "tawar-menawar".
\end{abstract}

Keyword: eksistensi, PNU, dan demokrasi terpimpin

\begin{abstract}
This paper was motivated by the success of Nahdlatul Ulama to become the most prominent Islamic political party during the Guided Democracy period. In addition, at the time, Nahdlatul Ulama Party (PNU) played an essential role in the national political scene as one of the main components of the "Nasakom" politics promoted by President Soekarno from religious circles. Even the PNU has the right to have representatives in all government commissions and organizations.
\end{abstract}


JNUS: Journal of Nahdlatul Ulama Studies, Vol. 3, No. 1, Januari 2021: 1-21

The main problem in this paper was: why did PNU manage to maintain its existence as an Islamic political party and become one of the main components of "Nasakom" politics during the Guided Democracy period? Based on these problems, several research questions were formulated: Why did NU turn into a political party? How was Sukarno's political policy during the Guided Democracy? What was the PNU's political stance during the Guided Democracy? The political existence of the PNU during the Guided Democracy was written using the historical method with a behavioristic approach. As for the spatial and temporal scope of the Soekarno government's research during the Guided Democracy period (1959-1965). The results showed that the PNU's stance was motivated by the attitude of PNU's dissatisfaction with the political policies of the Masyumi Party. PNU's participation in the 1955 General Election made PNU the third-largest political party after the PNI and the Masyumi Party. During the Guided Democracy period, the PNU tried to maintain its existence by supporting every political policy of Soekarno through support based on the principles of usbul figh, namely wisdom, flexibility, and moderation. Even in the decision-making process, there is often a bargaining process.

Keywords: existence, PNU, guided democracy

\section{INTRODUCTION}

In Islam, religion and politics cannot be separated. According to the Islamic view, al-Qur'an has regulated all aspects of human life thoroughly and organically (Ma'arif 1985:11). In other words, all human actions in any field must be guided by instructions sourced from the Koran, including in politics. Even though there are Islamic circles known as modernist Islamists who try to separate religion and politics, all Islamic ideas will still be built on the fundamental that the two sides go hand in hand and cannot be separated (Dhiauddin Rais 2001:5). This is the background why the Islamic movement in the world of politics in Indonesia is so strong, especially during the formation of the nation's "character" after Indonesia's independence.

As the largest Islamic organization at that time, Nahdlatul Ulama (NU) felt the need to be involved in political activities to fight for the aspirations of Muslims in a democratic country. In addition, the government's announcement dated November 3, 1945 regarding the formation of parties in Indonesia also influenced NU's involvement in the political arena. The peak was when NU, Muhammadiyah, and other Islamic organizations were incorporated into Masyumi, which was considered the only Islamic party based on the Islamic Conference on 7-8 November 1945 in Yogyakarta (Noer, 1987: 47-49). This has brought about a change in the orientation of NU leaders from religious and social issues to political ones (Haidar, 1998: 99).

In the early days of Masyumi's formation, the organizational structure placed NU as the Legislative Council in the Syuro Council (Party Council). Then, 
at the 2nd Masyumi Party Congress on 10-13 February 1946 in Solo, Masyumi placed NU as the party's defense division head. This position can determine the political direction in the composition of the Executive Board, especially in the Defense section. NU enthusiastically welcomed the shift towards an open role. At the 16th NU Congress in Purwokerto on 26-29 March 1946, an affirmation was made that NU was a notable member of the Masjumi party and encouraged its members to join the political party in droves. Thanks to the support of NU, the Masyumi party developed into one of the largest parties in Indonesia (Fealy, 2001: 53).

The reduced role of the ulema in Masjumi's political decision-making has led to divisions within the Masjumi body which are relatively complex. In addition, the granting of the minister of religion to a Muhammadiyah representative, namely Fakih Usman in the Wilopo Cabinet, was the cause of NU's disappointment with Masyumi. This caused NU to leave Masjumi and make NU a different political party. (Zuhri, 1979: 641).

Since May 1, 1952, the Nahdlatul Ulama Party (PNU) was established whose principle and aim was to uphold Islamic Sharia by leaning towards one of the schools of thought, namely Syafi'I, Maliki, Hanafi, and Hambali, as well as implementing Islamic laws in society. In July 1953 the PNU entered the cabinet of Ali Sastroamidjojo, led by the PNI and supported by the PKI. On the other hand, Masyumi and PSI emerged as the opposition (Feillard, 1999: 46-47). In this cabinet, PNU added to its political role, not only as minister of religion, but also minister of state. In fact, the post of deputy prime minister was given to PNU people.

PNU's success in the 1955 elections further solidified its position on the national political stage. PNU won $18.4 \%$ of the vote at the national level, ranking 3rd behind the Indonesian Nationalist Party (PNI) with 22.3\% and Masyumi with 20.9\% (Feillard, 1999: 49). This achievement is undoubtedly remarkable, considering that PNU is a new party. In addition, if PNU only obtained two ministerial positions in the previous cabinet, then in Ali's second cabinet, PNU has obtained five ministerial positions. Among them are the minister of home affairs, the minister of economy, the minister of social affairs, and the minister of religion, in addition to the position of deputy prime minister.

On the other hand, new problems emerged in the Ali II cabinet which was formed on the 1955 election coalition. This problem arose due to feuds between parties related to ideology, religion, and ethnicity. As a result, there was a crisis in the cabinet and the inability of the constituents to form a new constitution. Seeing such a situation prompted President Soekarno to issue a decree on July 5, 1959. This decree also initiated a new political system known as the Guided Democracy political system.

In the era of Guided Democracy, the relationship between PNU and Soekarno became increasingly important during these times. PNU is the largest 
JNUS: Journal of Nahdlatul Ulama Studies, Vol. 3, No. 1, Januari 2021: 1-21

Islamic party in the government. In this period, the PNU became one of the main components of the "Nasakom" politics from Soekarno's 'religious' circles.

Based on the description above, the main problem that will be studied in this research is why PNU managed to maintain its existence as an Islamic political party and became one of the main components of "Nasakom" politics during the Guided Democracy?

\section{RESEARCH METHODOLOGY}

This paper used the historical method carried out in stages: heuristics, source criticism, interpretation, and historiography. In the heuristic stage, the sources used are archives, newspapers, and secondary sources in books. Specifically, the archive data, namely the archives belonging to the Nahdlatul Ulama Organization from 1952-1966 and the State Gazette archives from 1959-1965. Likewise, the Duta Masjarakat newspaper is the main source that records the actual conditions in the temporal scope of this study so that it becomes a comparison material, in addition to the primary sources already mentioned.

The next stage in this research, namely source criticism. The authenticity and validity of the sources were obtained by cross-checking between sources, both archives, newspapers and secondary sources. Some of the facts obtained in this stage are then interpreted based on the approach used. Furthermore, the historiographical reconstruction is processual to frame the narrative in this paper.

In terms of approach, this study uses a behavioristic approach. This approach is intended to understand and analyze the political behavior of political actors in history. The main pressure, as stated in the research conducted by the Joint Research Center (2019: 37), is that political behavior, which then influences political decision making, is strongly influenced by social identity, life values, outlook on life, ideology and personal tendencies. The article further states that this component of behavior determination has a major influence on political actors in defining the world and at the same time influences it when political action must be taken. Therefore, starting from such an understanding, PNU's belief, especially related to the issue of the rules of ushul fiqh that it adheres to, becomes the main basis for understanding and analyzing the problems in this paper.

The principles of ushul fiqh strongly influenced PNU's political orientation and behavior. The principles of ushul figh often justify decisionmaking grouped into three main categories: wisdom, flexibility, and modernity (Fealy, 2001: 69). Wisdom is understood as a neutral political activity, namely taking actions conducive to avoiding losses. Three rules are commonly cited concerning minimizing risk or loss; a) dar 'al mafasid muqaddam 'ala jalb al-masalih, which means avoiding danger, takes precedence over doing good; b) when faced with two or more dangers, choose the least risk (sometimes also referred to as akhaffud-dararain, choose the lighter sin); 3) the danger must not be removed with the (other) danger. 
The same two statements were often quoted in the 1950s and 1960s as justifications for the behavior of the PNU (Fealy, 2001: 70).

Recommendations to avoid danger are often linked to two other, broader principles, namely maslahat and amar ma'ruf nabi munkar. Maslahat means seeking goodness or benefits and preventing mafsadah. Wahab Chasbullah repeatedly used this argument throughout the late 1940s and 1950s to justify his participation in the cabinet. In that case, amar ma'ruf nabi munkar becomes the basis for political pragmatism because only by participating in political power in the government can Muslims hope that Islamic law can be applied so that society can be protected from crime and danger (Fealy, 2001: 74).

Flexibility in the sense that PNU's political stance always tries as much as possible to adapt to situations and conditions and never proposes anything absolute or unconditional. At least 2 additional rules lead PNU to a flexible political stance; a) emergency allows all that is forbidden; 2) maa laa yudraku kullubu laa yutraku ba'dubu, what is not achieved $100 \%$, do not leave (throw away) only partial results (less than 100\%) (Fealy, 2001 "76).

Modernism can be interpreted as a desire to avoid extreme actions and act and express opinions. Moderate behavior, especially the tendency to choose a method commonly referred to as the "middle way approach, is found in both Islamic thought and the ideals of Javanese culture. This middle way approach also dominated PNU political thought during the 1950s and 1960s. After separating from the Masyumi Party in 1952, PNU promoted itself as a modern Islam which was another option outside of secular nationalist parties such as the PNI, PIR, PRN, and hard-line political parties as Masyumi. Hard-line to achieve a more harmonious and unified political condition (Feally, 2001: 80-85).

The above was carried out to ensure that Islamic law was implemented as well as possible, ensuring the improvement of the socio-economic conditions supporting its traditionalists and obtaining positions for PNU members in the government. The third meeting point of motivation is the assumption that social and economic progress is necessary for achieving Islamic goals (Fealy, 2001: 8687).

Based on the description above, it can be concluded that PNU's political behavior is more pragmatic. In that sense, the party's programs and policies are not rigidly bound to a particular doctrine and ideology. This is adjusted to the political situation and conditions that occur for the welfare of party members and voters and the survival of the party.

\section{Nahdlatul Ulama: From Religious Organizations to Political Parties}

At its inception on January 31, 1926, Nahdlatul Ulama (NU) was a jamiyah diniyah (religious organization). Although a religious organization, $\mathrm{NU}$ is involved in the Majelis Islam A'la Indonesia (MIAI). The federation of Islamic organizations aims to improve communication and cooperation among Muslims (Boland, 1985: 13; Fealy, 2003: 48). The idea for the formation of MIAI came from Wahab 
JNUS: Journal of Nahdlatul Ulama Studies, Vol. 3, No. 1, Januari 2021: 1-21

Chasbullah and Achmad Dahlan Kebondalem from NU, Mas Mansoer from Muhammadiyah, and W. Wondomiseno from Sarekat Islam (SI). However, during the Japanese government, precisely in October 1943, MIAI was disbanded and changed to Masyumi. This was done because, according to Japan, MIAI was founded on the initiative of Muslims as a federation of Islamic organizations with an anti-foreign attitude. The Japanese government only recognized Muhammadiyah and NU as legitimate members of Masjumi. This recognition brought NU into the government for the first time with Kiai Hasyim Asyari as chairman of Shumubu, the Office of Religious Affairs made in Japan.

Entering the realm of independence, NU played an active role in the struggle to defend Indonesia's independence by issuing the Jihad Resolution on October 22, 1945, which aimed to invite all Muslims to defend Indonesia's homeland, which had been free from colonial rule. This Jihad resolution contains that it is obligatory to fight for every capable Muslim within a radius of 94 kilometers from the place where the battle is taking place or where the enemy is. For those outside a predetermined radius, the obligation to participate is not imposed on each individual but on the community, which must send several community members to join the struggle (Ministry of Information of the Republic of Indonesia, 1954: van Bruinessen, 1994:61). In addition, Indonesia's demands for a parliament and amendments to the Indonesian constitution following the political manifesto issued by the government on November 3, 1945, regarding the implementation of a multi-party system in Indonesia, also encouraged NU to be involved in the political arena (Dhakidae, 1985: 202).

NU channeled its political aspirations through the Masjumi political party which is considered the only Islamic party, based on the Indonesian Islamic Conference on 7-8 November 1945 in Yogyakarta. The Masyumi Party was founded by four religious organizations, namely NU, Muhammadiyah, the Association of Muslims, and Muslims (Noer, 1987: 47-49). NU and other religious organizations, became special members by sending representatives to fight in the political arena.

Masyumi as an Islamic political party was established with the objectives of (1) upholding the sovereignty of the state and the religion of Islam and (2) implementing Islamic ideals in state affairs (Karim, 1983; 68-69). However, differences in the political interests of the various groups within the Masyumi body caused internal conflicts within this party, so that in $1952 \mathrm{NU}$ left the Masyumi Party.

There are many factors behind NU leaving the Masjumi Party, but those that directly influence the disappearance of the position of minister of religion from NU's hands and the reduced role of the ulama in political policymaking for the Masjumi Party. In addition, there is an uneven distribution of power between the traditionalist and modernist groups within the Masjumi Party (Fealy, 2003: 97). Therefore, based on the decision of the 19th Mukhtamar Jamiyah Nahdlatul 
Ulama on May 1, 1952 in Palembang, it was proclaimed NU to leave the Masyumi Party and make NU a different political party (Zuhri: 1979:641).

\section{PNU in the 1955 General Election}

The 19th congress on May 1, 1952 in Palembang was a new chapter for NU because it was decided that NU would become a political party at the congress. In the articles of association it is stated that 'This party is named Nahdlatul Ulama and is domiciled at the seat of its Executive Board. With the following principles and objectives, the Nahdlatul Ulama Party is based on Islam to enforce Islamic law which leans towards one of the schools of thought, namely Syafii, Maliki, Hanafi and Hambali. It implements the enforcement of Islamic laws in society (Ministry of Information, 1954: 414).

The first step taken by the PNU in the political field was to demand the government to carry out general elections immediately, to regularly and earnestly promote Pancasila education, especially the first principle which did not get enough attention and to agree with the government's will to save the state budget and eradicate unnecessary expenditures, honest and unfair (Aboebakar, 1957: 493).

As a new political party, PNU experienced many internal and external difficulties. The internal difficulties faced by PNU included reactions from NU figures who disapproved of NU leaving Masjumi. Therefore, the party issued a policy to remain with Masjumi or join the PNU membership.

In addition, the PNU experienced difficulties in obtaining skilled personnel with experience in the organization to carry out party tasks. Apart from internal factors, the difficulties faced by PNU came from external factors, namely the many pressures and attacks from outside, especially from Masjumi who brought down PNU (Mawardi, 1967: 29-30). Therefore, PNU devised a plan to address this critical problem. The plans drawn up included a rapid expansion of membership, the revival of its branches, and new sub-sectors to serve PNU support groups. The figure who played the most role in managing the PNU transition was Wahid Hasjim, the Young Chair of the PNU. Wahid managed the central administration, led the negotiations with Masyumi, became the architect of LMI,and was the initial impetus for implementing recruitment and policy making (Fealy, 2001: 137-138).

The strategy to overcome the first difficulty was that PNU immediately recruited skilled workers in the political field. The recruits must be Muslim and adhere to the four schools of thought or adherents of Ablussunah wal Jama'ah. In addition, one must obey the scholars, even though the obedience is formal. Among the skilled workers recruited by PNU were Idham Chalid, Imron Rosyadi, and Djamaluddin Malik (Anam, 1999: 246-247; Fealy, 2003: 142-144). After the first difficulty was resolved, the PNU immediately turned its attention to the issue of consolidating and saving the party's existence, both related to parliamentary membership and participation in the cabinet. However, a cautious and considerate 
JNUS: Journal of Nahdlatul Ulama Studies, Vol. 3, No. 1, Januari 2021: 1-21

attitude was still reflected in PNU's political behavior in its early stages of growth (Mawardi, 1957: 31-32; Anam, 1999: 248).

As a nascent party, PNU wants many votes in elections. Therefore, there is a need for an explanation to Muslims about the legal obligation to participate in elections. So on April 11-15, 1953, Islamic leaders held a MUkhtamar Alim Ulama throughout Indonesia in Medan, and decided as follows: 'it is obligatory for Muslims to take part in elections, both for members of the DPR and constituents (Anam, 1999: 249). In addition, on September 8-13, 1954, the PNU held its 20th Congress in Surabaya. This congress is consolidation work to face the upcoming elections. All attention is directed to political issues because the elections to be held on September 29, 1955, for members of the DPR and December 15 to elect members of the Constituent Assembly are important moments to measure the potential of the PNU and determine the fundamental destiny of the country.

The final result of the vote shocked PNU leaders and political observers alike. PNU won around 6,955,141 votes or $18.4 \%$ of the total national vote. This result also places PNU as the third-largest party after the Indonesian National Party/ PNI (22.3\%) and Masyumi (20.9\%). This achievement is undoubtedly extraordinary, considering that PNU is a new party. The increase can see in members of parliament from 8 seats in the DPRS to 45 seats. In addition, if in the previous cabinet PNU only obtained two ministerial positions, in this new cabinet PNU has five positions, namely the Minister of Home Affairs (MR. Sunarjo), Minister of the Economy (Burhanuddin Harahap), Minister of Social Affairs (KH Fatah Jasin), Minister Religion (KH Iljas) and lastly as Deputy Prime Minister (Idham Chalid) (Anam, 1999: 251 - 252; Karim, 1995: 59).

PNU's success in the 1955 General Election certainly changed the national political map. As stated by K.H. Saifuddin Zuhri, the success of the PNU in the 1955 elections raised the prestige of Muslims in the political stage in parliament and in the cabinet. The PNU's third position in the 1955 General Election would never have been achieved if the PNU had remained in Masyumi. This success is also proof of the PNU masses' greatness, which was always demanded when NU was still in Masyumi (Anam, 1999: 251 - 252).

\section{PNU's involvement in the Constituent Assembly}

The Constituent Assembly has the task of drafting a new law to replace the 1950 Constitution. This Council was formed in November 1956 and its last session took place in June 1959. All decisions concerning amendments to the constitution require the support of two-thirds of the Council (Fealy, 2001: 274). ). The Constituent Assembly is divided into three ideological factions, namely, first, the Pancasila block, which considers the five precepts to be the basis of the state; second, the Islamic bloc that proposes Islam as the basis of the state; and third, socio-economic, which proposes social economy and democracy following Article 33 and Article 1 of the 1945 Constitution as the basis of the state. 
The report of the Constitutional Preparatory Committee also contains five points of agreement based on the state. The five points of this agreement are intended to facilitate reaching a consensus. However, it later turned out that these five points of agreement were used to promote the truth of their respective ideologies (Nasution, 1995:50).

For almost half a year, the Constituent Assembly still debated the fundamental question of the state. This debate is an ideological confrontation between supporters of Pancasila and adherents of Islam. Each emphasizes the superiority of the ideology it proposes. According to its supporters, Pancasila is considered a true platform for every ideology in Indonesia because it is in accordance with the Indonesian personality, and only Pancasila can unite the heterogeneous Indonesian society. Meanwhile, according to the Islamic block, Islam is a divine revelation that contains the most complete and perfect laws and teachings to regulate individual or community life and regulate religious, political, and economic issues (Nasution, 1995: 52).

In the sessions of the Constituent Assembly, the PNU has always given full support to the proposal for the establishment of an Islamic state. Several reasons were put forward in this regard. First, Islam can be the basis of a solid state because it is based on God's last word, namely Q.S Al-Maidah verse 3. Islam is God's law, a law without flaws, made by Allah the Most Perfect. Islam cannot be separated from religious, political and state issues.

Meanwhile, Pancasila is only an artificial concept without a system or substance vulnerable to communist and non-religious interpretations. Second, Islam must be used as the basis of the state because $90 \%$ of Indonesian people are Muslim. Third, Islam offers a comprehensive and progressive foundation for a modern state because it contains the main principles as stated in the constitution (Fealy, 2001: 275-276).

In 1957, the Islamic bloc proposed that the Jakarta Charter be included in the preamble to the new draft law to explain Pancasila. The Islamic bloc initially responded positively to the proposal, but they soon withdrew their support after PNI and Masyumi confirmed their stance on the proposed compromise. PNU and several other Islamic organizations still consider the inclusion of the Jakarta Charter as a top priority (Fealy, 2001: 277).

\section{Indonesian Political Condition Ahead of Guided Democracy}

The ratification of the political manifesto on November 3, 1945 by the Working Body of the Central Indonesian National Committee (BPKNIP), which Mohammad Hatta signed as vice president; therefore, since then, Indonesia has adhered to the multi-party Indonesian party system. Viewed from the other side, November 3, 1945, can be the beginning of the Liberal Democracy political system or the Parliamentary Democracy political system (Kantaprawira, 2002: 188). As a further manifestation of the implementation of the Liberal Democracy political system, the leadership of the cabinet from President Soekarno was 
JNUS: Journal of Nahdlatul Ulama Studies, Vol. 3, No. 1, Januari 2021: 1-21

handed over to Prime Minister Soetan Sjahrir (Poesponegoro and Notosusanto, 1992: 124).

The existence of Sjahrir's cabinet, which was the first parliamentary cabinet, can be said to be relatively short-lived. This happened due to the diplomatic policy taken against the Dutch through negotiations which led to a strong opposition spearheaded by Persatuan Perjuangan (PP) organization led by Tan Malaka and followed by 137 organizations. The opposition's attitude shown by the PP eventually gave rise to a "motion of no confidence" against Sjahrir's cabinet at the Central Indonesian National Committee (KNIP) meeting in Solo, February 28, 1946. Therefore, Sjahrir handed back his mandate to President Soekarno (Noer, 1987). : 154-157).

However, on March 2, 1946, Prime Minister Sutan Sjahrir was again appointed by President Soekarno as prime minister in the Cabinets of Sjahrir II and Sjahrir III. Sjahrir III's Cabinet was the last cabinet he led due to the diplomatic policies he pursued in dealing with the Dutch through the Linggarjati negotiations on November 10, 1946. The Netherlands recognized the Republic of Indonesia de facto in Java, Madura, and Sumatra. Opposition arose to overthrow Sjahrir, so on June 27 1947, Sjahrir handed over his mandate to the President (Anam, 1999: 233; Noer, 1987: 169).

The relative shortage experienced by Sjahrir I Cabinet subsequently became the distinctive color of the government of subsequent cabinets, such as the Sjahrir II Cabinet (March 12, 1946 - October 2 1946), Sjahrir III Cabinet (October 2, 1946 - July 3, 1947), Amir Sjarifuddin Cabinet I (July 3, 1947 November 11, 1947), Amir Sjarifuddin II Cabinet (November 11, 1947 - January $29,1948)$. The only parliamentary cabinet government that was relatively old in the first era of Liberal Democracy was the Hatta I Cabinet, which lasted from January 29, 1948, to August 4, 1948. Then the Hatta I Cabinet was replaced by the Emergency Cabinet led by Sjafruddin (December 19, 1948 - July 13, 1949), but was held again by Hatta until December 20, 1949 (Poesponegoro and Notosusanto, 1992: 659).

The cabinet upheaval was so fierce in the first era of Liberal Democracy, it can be said that it got sharper in the second era, which began after the rebirth of the Unitary State of the Republic of Indonesia on August 17, 1950. At least at this time, there were seven parliamentary cabinets. The seven parliamentary cabinets were the Natsir Cabinet (September 6, 1950 - April 27, 1951), the Sukiman Cabinet (April 27, 1951 - April 3, 1952), the Wilopo Cabinet (April 3, 1952 - August 1, 1953), the Ali Sastroamidjojo I Cabinet (August 1, 1953 August 12, 1955), Burhanuddin Harahap Cabinet (August 12, 1955 - March 24, 1956), Ali Sastroamidjojo II Cabinet (March 24, 1956 - April 9, 1957), and finally, the Karya Cabinet led by Djuanda (April 9, 1957 - July 10, 1959) (Poesponegoro and Notosusanto, 1992: 659).

Unlike the first era, the second era of Liberal Democracy was marked by the ups and downs of the cabinet, also marked by general elections, which were 
held on September 191955 for the parliament and December 151955 for the constituents. The general election was attended by 36 contestants from political parties and 39 million voters. Of the 36 parties participating in the general election, only 27 political parties won seats (Dhakidae, 1985: 203). Among the 27 parties that won seats, four political parties managed to occupy the top four. The four parties are Masjumi, PNI, PNU and PKI. The details of the seats that were successfully obtained were Masyumi, 57 seats; PNI, 54 seats; PNU, 45 seats; and the PKI, 39 seats (Poesponegoro and Notosusanto, 1992: 227-230).

Although the government of Burhanuddin Harahap's Cabinet managed to make quite a proud political achievement, the desired political stability was still not achieved. Moreover, during the elections, the constituents who were tasked with drafting a Basic Law (UUD) instead of the 1950 Provisional Constitution failed several times due to prolonged conflicts between political parties to reach a final decision. This very alarming situation ultimately places political parties in a very critical position. Various scathing comments immediately appeared towards political parties, ranging from those who judged political parties to be incompetent to work to suggest the formation of a youth junta as a substitute for political parties (Dhakidae, 1985: 203).

Facing these conditions, President Soekarno did not remain silent. Slowly but surely, President Soekarno began to play an active role again. Approximately one year after the election, in a speech delivered on 28 and 30 October 1956, President Soekarno recommended burying all political parties (Feith and Castles (Ed), 1988: 64). As a continuation of his offer, on February 21, 1957, President Soekarno then presented the idea of Guided Democracy. The conception conveyed by Soekarno contained two main things, namely the formation of the National Council and the Gotong Royong Cabinet. The Gotong Royong Cabinet that Soekarno meant was "a cabinet in which all parties or factions in parliament are seated which are sufficient to achieve the kies quotient" (Feith and Castles (Ed), 1988: 68). The National Council recommended by Soekarno had the function of providing advice to the cabinet, whether requested or not (Feith and Castles (Ed), 1988: 70 - 71).

Finally, after the constituents were proven unable to carry out their duties to form a new constitution, on April 22 1959, President Soekarno recommended the constituents to make the 1945 constitution the permanent constitution of the Republic of Indonesia. The constituents then discussed Soekarno's proposal. However, in the constituent assembly regarding Soekarno's proposal, the constituents again experienced difficulties in reaching a quorum (Poesponegoro and Notosusanto, 1992: 282).

Starting from these conditions, to save the country and based on the staatsnoodrecht (law of the state of danger for the state), President Soekarno issued on Sunday July 5,1959 at around 17.00 WIB a decree. The main contents of the presidential decree, among others, are stipulating the dissolution of the constituent assembly, the stipulation of the re-enactment of the 1945 Constitution 
JNUS: Journal of Nahdlatul Ulama Studies, Vol. 3, No. 1, Januari 2021: 1-21

for the entire Indonesian nation and the entire homeland of Indonesia. To balance this decision, it was also decided to revoke the 1950 Provisional Constitution and plan the formation of the Provisional MPR and Temporary DPA (Community Ambassador, Monday, July 6 1959).

With the issuance of the Presidential Decree on July 5 1959, the era of Liberal Democracy which lasted for approximately 14 years ended. The end of the Liberal Democracy political system became clearer after President Soekarno, on July 5, 1959, dissolved the last parliament led by Djuanda and replaced it with a working cabinet under the leadership of President Soekarno himself (Poesponegoro and Notosusanto, 1992: 311).

\section{The Politics of the Nahdlatul Ulama Party during the Guided Democracy}

The inability of the Constituent Assembly to create a new state constitution and constitution as a replacement for the 1959 Constitution caused a political crisis in Indonesia. Therefore, in January 1959, Sukarno, supported by the military, proposed a plan to end the political crisis and complete the transition to the Guided Democracy political system. President Soekarno called for a return to the 1945 Constitution. To launch his plan, President Soekarno persuaded the PNU as one of the largest Islamic parties at that time to accept his proposal. However, the Jakarta Charter became an obstacle, because the PNU wanted the Jakarta Charter to be included as the Preamble to the 1945 Constitution, but President Soekarno rejected it (Fealy, 2001: 278-279).

Based on the Daily Executive Meeting on February 19 1959, the PNU finally supported President Soekarno's call to return to the 1945 Constitution (Zuhri (Comp.), 1962: 111). The decision was taken with the understanding that accepting the 1945 Constitution meant accepting everything around the "historische documenten" including the "Djakarta Charter" as the material and spirit of the 1945 Constitution" (Community Ambassador, February 23 1959:1 \& 3). PNU defended its decision by saying that it was carried out based on deliberation to overcome the difficulties faced by the people and the state, by taking a 'middle way' that did not conflict with the 'ideological core' and 'human beliefs' that PNU upheld. Pancasila Islam" as the basis of the state caused PNU to take this step, noting that the 1945 Constitution was inspired by the Jakarta Charter (Zuhri (Comp.), 1962: 107-108).

Re-acceptance of the 1945 Constitution as the Constitution of the Republic of Indonesia by the PNU, the PNU automatically accepts the birth of the Guided Democracy political system in Indonesia. Using the pretext of 'amar maruf nabi munkar', the PNU accepted Guided Democracy. This was done to avoid the dangers and benefits of the party from the risk of PNU being expelled from Guided Democracy. This shows the attitude of the PNU struggle during the transition period. PNU's non-rigid attitude made it easy for the party to adapt to any political situation. Although the PNU could not defend its proposal to include the Jakarta Charter in the Preamble to the 1945 Constitution, it did not suffer a 
total failure. The Presidential Decree of July 5 acknowledged that the Jakarta Charter 'animates the 1945 Constitution'.

Idham Chalid, in his speech in front of PNU members at the 35th anniversary of PNU (Community Ambassador, January 27, 1960: 1), stated that Guided Democracy is not democracy led by individuals, but by wisdom in representative deliberation. In other words, Guided Democracy contains the notion of deliberation as its core.

Regarding the idea of "Guided Democracy", PNU has determined that Guided Democracy must remain a democracy; however the emphasis remains on democracy, not on its leadership. Democracy without leadership will lead to anarchy, and leadership without democracy will lead to dictatorship, which means piety, the ideals of independence, and the 1945 Constitution. Regarding the idea of "Indonesian-style socialism", the realization remains socialism based on all the precepts in Pancasila and does not conflict with Islamic principles (Zuhri, 1979: 652-653).

In September 1959, DPAS proposed that the President's state speech on August 171959 entitled "The Rediscovery of the Indonesian Revolution" was made into the GBHN and referred to as the Political Manifesto of the Republic Indonesia (Manipol). The DPAS proposal received MPRS legalization through MPRS Decree No. 1/ MPRS/1960. In that decree, the MPRS established the Political Manifesto as GBHN and the President's speech on August 17, 1960, entitled "The Way of Our Revolution" and a speech on September 30, 1960, before the UN General Assembly entitled "To Build The World A New " as guidelines for implementing Manipol (Poesponegoro and Notosusanto, 1992: 313-314).

The contents of the manipol are then summed up into five principles, namely: the 1945 Constitution; Indonesian Socialism; Guided democracy; Guided Economy; and Indonesian Personality. The five principles are collected in the word USDEK. So it is better known as the USDEK Manipol. After being associated with Pancasila, the USDEK Manipol by the government became a series of patterns of Guided Democracy ideology. However, at the end of 1960, Soekarno complemented the ideology of the Indonesian state with the slogan Nasakom, namely the doctrine of the unity of the three elements of Indonesian society consisting of the Nationalist group, the Religious group, and the Communist group (Nas-A-Kom) (Boland, 1985: 106).

Nasakom is considered the Indonesian nation's ideological reality, which cannot be avoided, as described in President Soekarno's mandate on August 17, 1960, The Way of Our Revolution (Djarek). The formulation of this mandate eventually gave birth to the slogan Nasakom Jiwaku. Therefore, Nasakomization began to be developed in all state institutions, both DPAS, DPR-GR, National Front, etc. Such was President Soekarno's determination to realize his Nasakom concept. At that time, no political party resisted President Soekarno's political 
JNUS: Journal of Nahdlatul Ulama Studies, Vol. 3, No. 1, Januari 2021: 1-21

stance. The political constellation of that period was divided into three axes, the PKI, the military and President Soekarno. (Anam, 1999: 272-273).

Seeing President Soekarno's political tendencies during the Guided Democracy period, the PNU was more defensive and supported the Nasakom movement to facilitate the inclusion of PNU in the new cabinet. PNU chose the path to support Nasakom not in terms of personnel but as an attitude of accepting the reality of the three ideologies that exist in Indonesia. By accepting this political policy, PNU succeeded in becoming the main component of the religious organization's members of Nasakom. Based on the Verslag PB NU Daily Meeting on February 25, 1960, it was decided that PNU accepted the USDEK Manipol as a stepping stone to achieving the party's goals and ideals in the Articles of Association. Thus, the struggle to uphold Islam is still open and mandatory for Muslims to fight for it (ANRI, NU Archives Collection, Verslag Daily Meeting of the Nahdlatul Ulama Syuriyah Executive Board, February 25, 1960, Map No. 3).

The PNU struggle within Nasakom attempted to oppose the entry of the PKI into the government vehemently, but most accepted it without rebuttal. PNU leaders legitimize their participation in Guided Democracy with a rule of ushul figh which states that "in a situation where one has to make one of two choices, even though neither of the two is ideal, one should choose the one that does the least damage." In this case, the greatest damage is to allow the Guided Democracy government to take place, which involves the communists without the involvement of Muslims in it (van Bruinessen, 1994:82-83).

In order to support the running of the Guided Democracy political system following the Manipol Usdek, President Soekarno carried out a 'retooling' in the government. This reshuffle was carried out on state institutions, the establishment of new state institutions, a reshuffle in the party, a reshuffle in the legislature, a reshuffle in the executive field, a reshuffle in the area of local government, an overhaul in the judiciary and in the personnel field (Amin, 1966: 39-79). )

The first step, President Soekarno formed the MPRS and DPAS through Presidential Decree No. 2 of 1959 and Presidential Decree No. 3 of 1959. In addition, President Soekarno formed the National Front through Presidential Decree No. 13 of 1959. However, on the other hand, President Soekarno on March 5, 1960 through Presidential Decree No. 3 of 1960, dissolved the DPR due to the 1955 General Election. This was done because the DPR rejected the APBN proposed by President Soekarno. Instead, President Soekarno on June 241960 composed the composition of the new DPR, which was named the Gotong Royong People's Representative Council (DPR - GR) (Poesponegoro and Notosusanto, 1992: 311-312).

The new legislative structure, which includes representatives from functional groups and the military and reduces members from parties, was determined by President Soekarno in Tampaksiring with 261 members, including 130 from political parties, 95 from functional groups 36 representatives from the military. Of these. NU won 35 seats represented by political parties and 15 seats 
represented by functional groups (Fealy, 2001: 289). Members of the DPR-GR appointed by President Soekarno, must approve the 1945 Constitution, Indonesian-style Socialism, Guided Democracy, Guided Economy and Indonesian Personality and be willing to participate in implementing the Political Manifesto of the Republic of Indonesia dated August 171945 (ANRI, NU Archives Collection, Stipulation of the President of the Republic of Indonesia). Indonesia No. 4 of 1960 concerning the Composition of the Gotong Royong People's Representative Council, June 24 1960, Map No. 85). Based on the election by its members, the leadership of the DPR-GR consists of: Chairman $\mathrm{H}$. Zainul Arifin (PNU), deputy chairman Arudji Kartawinata (PSII), Subamia (PNI), Rear Admiral Mursalin (Navy), and M.H. Lukman (PKI). Meanwhile, the leadership of the MPRS consists of: Chairul Saleh (Murba- Generation '45), Deputy Chair Mr. Ali Sastroamidjojo (PNI), K.H. Idham Chalid (PNU), Brigadier General Wiluyo Puspoyudo (TNI-AD), and D.N. Aidit (PKI) (Zuhri, 1987: 438).

The agreement in Tampaksiring created a feud within the PNU over the legitimacy of the law and the composition of the new parliament. Some NU figures led by Bisri Syamsuri said that the DPR-GR was "ghasab", that is, the usurpation of the rights or property of others. Based on this interpretation, Soekarno's actions against the previous parliament had robbed voters of their rights in the 1955 elections and dismissed members of parliament. If PNU accepts a position in the DPR GR, it means that PNU has allowed it, even taken advantage of actions that violate the law (Fealy, 2001: 290).

Despite much criticism, the PNU moved quickly to accept the results of the agreement. They cite "amar maruf nabi munkar" as the main reason, saying that the Islamic community should have representatives in parliament. In addition, PNU was worried that representatives of the communist group would replace the positions left by PNU members. Finally, the Party Council decided to accept the interpretation of "amar maruf nabi munkar" and approved to join the DPR GR on the condition that the representation of Islamic groups must be increased. On June 17, 1960, President Soekarno agreed to add 22 members, 16 of whom were representatives from Muslim functional groups. In the face of an atmosphere of conflict and to prevent further divisions, the plenary session of the PBNU on 2324 June 1960 finally decided to 'give freedom to NU members who were appointed as members of the DPR GR to accept or reject the appointment depending on whether they saw it as part of the "commandment". maruf nahi munkar" or "ghasab" (Fealy, 2001: 291-294)

In the DPR-GR membership, there are no representatives of political groups or parties from the Masjumi Party, PSI, Labor Party, PRI and other parties deemed by the government to be unable to meet the requirements as stated in Presidential Decree no. 7 of 1959 and Presidential Regulation No. 13 of 1960 concerning Recognition, Supervision and Dissolution of Parties. Furthermore, the dissolution or rejection of the recognition of the parties is carried out in the form of a Presidential Decree, namely: Presidential Decree no. 200 of 1960 dated 
JNUS: Journal of Nahdlatul Ulama Studies, Vol. 3, No. 1, Januari 2021: 1-21

August 171960 which in its dictum reads: "dissolve the Masjumi Political Party, including its parts/branches throughout the territory of the Republic of Indonesia". Presidential Decree No. 201 of 1960 dated August 17, 1960 which in its dictum states: "Dissolve the Indonesian Socialist Party including its parts/branches/branches throughout the territory of the Republic of Indonesia". Presidential Decree No. 129 of 1961 dated April 14 which in its dictum reads: "Refusing to recognize as a party as referred to in Article 4 of Presidential Regulation No. 13 of 1960: the Indonesian Islamic Sarekat Party - Abikusno Cokrosuyoso; National People's Party - Freea Daeng Lalo; Indonesian People's Party; and National People's Party - Jody Gondokusumo (Soebagijo, 1982: 207).

Indeed, there had previously been reactions from parties, including the leadership of the PNU and PNI. PNU then left it to each member to determine their attitude in dealing with the turbulence of such a situation. The support provided by PNU in the process of political restructuring greatly helped secure its position in the Guided Democracy system. The dissolution of Masjumi in September 1960 made PNU the single largest Islamic party and the main religious component of Sukarno's Nasakom. In fact, their influence, like that of the PNI, was waning, as power was increasingly concentrated in the hands of the President, the military, and the PKI. Nevertheless, the PNU could still use its position in government to build an organizational structure and patronage network and counter the PKI activities.

In addition to making changes in his government, both in the field of superstructure and infrastructure, the Guided Democracy period was marked by political events related to the appointment of Soekarno as President for life. The policy for the appointment of a president for life against President Soekarno is based on the General Assembly of the MPRS which is stipulated in Article 1 of MPRS Decree No. III/ MPRS/1963 on May 18 1963. The decree was signed by the chairman and representatives of the MPRS, namely Chairul Saleh (Murba), Ali Sastroamodjojo (PNI), Idham Chalid (PNU), D.N. Aidit (PKI) and Walujo Puspojudo (Army) (Maarif, 1996: 107). The election of Soekarno as President for life is contained in Article 1 MPRS Decree No. III/ MPRS/1963 with the following considerations: During the Indonesian Revolution, Soekarno as the Great Leader of the Indonesian Revolution has succeeded in leading this revolution by achieving victories, as we can all enjoy together until now; Soekarno's personality is the embodiment of the combination of revolutionary leadership and state leadership and is a unifier of all revolutionary people's forces so that he fulfills the requirements as President both in terms of revolution, in terms of the 1945 constitution, as well as in terms of religion in general, especially Islam as waliyul amri; The strong desire of various groups of people and regions of the Republic of Indonesia for Soekarno as the Great Leader of the Revolution who is now the President of the Republic of Indonesia to be appointed President for life (Ambassador of the Community, May 30 1963). 
For this decision, the PNU justified and supported it with members of the Muslim League. The Islamic parties under the leadership of the PNU with spokesman Achmad Sjaichu revealed that there were three reasons to justify the appointment of President Soekarno as President for life: (1) Based on political considerations, Soekarno contributed greatly to the struggle for Indonesian independence. Under Sukarno's leadership, West Irian was able to return. within the Unitary State of the Republic of Indonesia. Therefore, Soekarno deserves to be appointed as President for life as the highest honor; (2) Through revolutionary considerations, Sjaichu compared Soekarno with the Prophet Muhammad who led the revolution in Arabia in the 6th century AD. With these negotiations, according to Sjaichu's considerations, the politics carried out by President Soekarno were under Islamic principles. Therefore, the best attitude was to give full support to Soekarno's leadership (Community Ambassadors, May 211963 and May 22 1963); Based on religious considerations, Sjaichu as a spokesman for the Islamic group at the MPRS stated as follows: "Throughout the history of Islam, it has never been found that there is an election of a Head of State with a time limit of 5 years or ten years, as long as the Head of State fulfills the leadership requirements...." ( Community Ambassador, May 22, 1963); (3) Based on the decision of the Indonesian Ulama Alim Di Cipanas in 1963 which appointed President Soekarno as waliyyul amri bidaruri, namely the head of government in the fields of government and state as well as in the field of religion. (Community Ambassador, May 22 1963).

With the three considerations above, the more perfect the political ijtihad of the Islamic groups in the MPRS to support the decision contrary to the 1945 Constitution which was actually to be re-implemented after the Presidential Decree of July 5, 1959. In addition to the Islamic group, Wahab Chasbullah issued a fatwa regarding the obligation of President Soekarno to accept the decision of MPRS. Thus, the PNU demonstrated its overall political stance that supported President Soekarno as President for life (Maarif, 1996: 110-111)

\section{CONCLUSION}

Based on the description above, it can be concluded that Nahdlatul Ulama was founded on January 31, 1926 as an association of ulama and santri in the pesantren environment. Initially this organization was a jam'iyah diniyah but NU's involvement in MIAI changed the orientation of NU leaders from religious and social issues to political matters. Until early 1952, NU channeled its political aspirations into the Masyumi party. This year NU took a bold step by leaving the Masjumi party and establishing its own political party, the Nahdhatul Ulama party. In the first general election in 1955, the it became the third-largest party after the PNI and the Masyumi party.

Entering the era of Guided Democracy, to support the conception of guided democracy and the Manipol Usdek, Soekarno changed the superstructure and infrastructure in his government. The political policies carried out by 
JNUS: Journal of Nahdlatul Ulama Studies, Vol. 3, No. 1, Januari 2021: 1-21

Soekarno at this time included the issuance of a presidential decree and the enactment of the Guided Democracy period, Nasakom's political policies, retooling of state institutions, the formation of new state institutions, reforms in the party sector, reforms in the legislative field, changes in the executive sector, reforms in the field of local government, reforms in the judiciary and personnel fields.

The PNU's attitude towards Soekarno's various political policies during the Guided Democracy period was dynamic and positive in the sense that PNU supported all of President Soekarno's political policies. Even though the PNU accepts all of Soekarno's policies, there is often a bargaining process in making decisions. PNU did this to secure the position of the party, party supporters, the aspirations of the Islamic community, and the interests and integrity of the Indonesian nation and state.

\section{REFERENCES}

\section{Documents}

ANRI. NU Archive Collection, Surat Keputusan Pengurus Besar Partai Nahdlatul Ulama, 3 October 1965, Map No. 182.

ANRI. NU Archive Collection, Sekitar Peraturan Kepartaian, 14 July 1960, Map No. 2.

ANRI. NU Archive Collection, Pelaksanaan Per. Pres. No. $9 / 39$ dan Per. Pres. No. 13 tahun 1960, 20 April 1961, Map No. 2.

ANRI. NU Archive Collection, Penetapan Presiden Republik Indonesia No. 7 Tabun 1959 tentang Syarat-syarat dan Penyederhanaan Kepartaian Presiden Republike Indonesia, 31 December 1959, Map No.2.

ANRI. NU Archive Collection, Peraturan Presiden No. 13. 1960 tentang Pengakuan Pengawasan-Pembubaran Partai-partai, 12 July 1960, Map No. 2.

ANRI. NU Archive Collection, Pernyataan Bersama Partai-partai dan Ormas-ormas Islam tentang 'Tekad Membela Agama Islam dan Umat Islam untuk Memenangkan REVOLUSI dan Memperkokoh Persatuan Nasional yang Progresif Revolusioner yang Berporoskan NASAKOM, 12 March 1965, Map No. 106.

ANRI. NU Archive Collection, Bahan tentang Perincian Manifesto Politik Presiden Oleh Sunirjo-Pokok-pokok Pikiran Manifesto Politik yang Diucapkan Oleh Presiden Soekarno pada Tanggal 17 August 1959), 1 October 1960, Map No. 184.

ANRI. NU Archive Collection, Bahan tentang Perincian Manifesto Politik Presiden dari Saifuddin Zubri, 1 October 1960, Map No. 184.

ANRI. NU Archive Collection, Verslag Rapat Harian Pengurus Besar Syuriyah Nabdlatul Ulama, 25 February 1960, Map No. 3.

ANRI. NU Archive Collection, Musyawarah Harian Pengurus Besar Syuriyah Nadlatul Ulama, 25 February 1960. Map No. 85. 
ANRI. NU Archive Collection, Penetapan Presiden Republik Indonesia No. 4 Tabun 1950 tentang Susunan Dewan Perwakilan Rakyat Gotong Royong, 24 Juni 1960. Map No. 85.

ANRI. NU Archive Collection, Deklarasi MPRS Republik Indonesia tentang Berdiri di Atas Kaki Sendiri, April 1965, Map No. 267.

ANRI. NU Archive Collection, Laporan Pekerdjaan Fraksi NU dalam DPR-GR dalam Masa Sidang Pertama Tahun 1960/ 1961, 1 November 1960, Map No. 260.

ANRI. NU Archive Collection, Siaran ke-13/Tabun 1960 mengenai UUD 1945, Manipol dan Pen. Pres 7/ Per. Pres 13, 18 August 1960, Map No. 262.

ANRI. NU Archive Collection, Pernjataan Kebulatan Tekad Pelaksanaan Tri Komando Rakjat, 2 March 1962, Map No. 89.

ANRI. NU Archive Collection, Pernjataan Kebulatan Tekad 10 Partai Politik, Tahun 1964, Map No. 118.

ANRI. NU Archive Collection, Piagam Pembentukan badan Musjawarah Partai-partai dan Organisasi-organisasi Islam, 21 May 1963, Map No. 272.

ANRI. NU Archive Collection, Peraturan Dasar Badan Musjawarah Partai-partai dan Organisasi-organisasi Islam, Map No. 272.

ANRI. Presidential Decree of 1959, Penetapan Presiden Republik Indonesia No. 7 Tabun 1959 tentang Sjarat-sjarat dan Penjederhanaan Kepartaian, Map No. 8.

ANRI. Cabinet secretary Archive Collection, Peraturan Presiden Tahun 19591960, Peraturan Presiden No. 13 Tabun 1960 tentang Pengakuan, Pengawasan dan Pembubaran Partai-partai, Map No. 28.

ANRI. Collection of Speeches of the President of the Republic of Indonesia 1952-1967, Pidato PJM Presiden Soekarno pada Rapat Raksasa di Lapangan Merdeka untuk. Menjambut Masuknja Irian Barat ke dalam Wilayah Kekuasaan Republik Indoneisa, 1 May 1963, Map No. 487.

ANRI. Collection of Speeches of the President of the Republic of Indonesia 1952-1967, Amanat Komando Presiden/ Panglima Tertinggi/ Pemimpin Besar Revolusi Indonesia pada Appel Besar SUkarelawan Pengganjangan Malaysia di Depan Istana Merdeka Djakarta, 3 May 1964, Map. No. 598.

ANRI. Archive Collection of Roeslan Abdulgani, Pernjataan Bersama Liga Demokrasi, 24 March 1960. Map No. 189.

Pusat Dokumentasi Lakpesdam, NU history documents, Keputusan Mu'tamar Partai NU Ke-22 di Jakarta, 18 December 1959.

Pusat Dokumentasi Lakesdam, NU history documents, Keputusan Mu'tamar XXIV 4-9 July 1967 di Bandung, 10 July 1967.

\section{Books}

Aboebakar (Atjeh), H. (Ed). 1957. Sejarah Hidup K. H. Wabid Hasjim dan Karangan Tersiar, Jakarta: Panitia Buku Peringatan Alm. K. H. A. Wahid Hasjim.

Alam, Wawan Tunggal (Ed). 2001. Bung Karno, Demokrasi Terpimpin Milik Rakyat Indonesia (Kumpulan Pidato). Jakarta: Gramedia Pustaka Utama. 
JNUS: Journal of Nahdlatul Ulama Studies, Vol. 3, No. 1, Januari 2021: 1-21

Amin, S. M. 1967. Indonesia di Bawah Rezim Demokrasi Terpimpin. Jakarta: Bulan Bintang.

Anam, Choirul. 1999. Pertumbuban dan Perkembangan Nabdlatul Ulama. Cetakan ke2. Surabaya: Bisma Satu.

Baidlawi, Masduki dan Saifullah Ma’shum. 1991. Kembali ke Pesantren (Kenangan 70 Tahun K. H. Agmad Sjaichu). Jakarta: Yayasan Islam al Hamidiyah.

Barton, Greg dan Greg Fealy (Ed). 1997. Tradisionalisme Radikal Persinggungan Nahdlatul Ulama-Negara. Yogyakarta: LKiS.

Boland, B. J. 1985. Pergumulan Islam di Indonesia 1945-1970. Terjemahan oleh Saafroedin Bahar. Jakarta: Garfiti Pers.

Budiardjo, Miriam. 2002. Dasar-dasar Imu Politik. Cetakan ke-22. Jakarta: Gramedia Pustaka Utama.

Dhakidae, Daniel. 1985. 1985 .Partai Politik dan Sistem Kepartaian di Indonesia”, hal. 189-225, dalam Faarchan Bulkin (Pengantar), Analisa Kekuatan Politik di Indonesia, Jakarta: LP3ES.

Fealy, Greg. 2003. Ijtihad Politik Ulama, sejarah NU 1952-1967. Terjemahan oleh Farid Wajidi dan Mulni Adelina Bachtar. Yogyakarta: LKiS.

Feillard, Andree, 1999, NU vis-avis Negara, Pencarian Isi, Bentuk dan Makna. Terjemahan oleh Lesmana. Yogyakarta: LKiS.

Feith, Herbert, 1995, Soekarno-Militer dalam Demokrasi Terpimpin. Jakarta: Pustaka SInar Harapan.

Feith, Herbert dan Lance Castles (Ed.). 1988. Pemikiran Politik Indonesia 1945-1965. Terjemahan oleh LP3ES. Jakarta: LP3ES

Haidar, M, Ali 1998. Nabdatul Ulama dan Islam di Indonesia, Pendekatan Fikih Dalam Politik. Cetakan ke-2. Jakarta: Gramedia Pustaka Utama.

Indonesia, Departemen Luar Negeri. 1971. Dua Pulub Lima Tahun Departemen Luar Negeri 1945 - 1970. Djakarta: Direktorat Djenderal Research, Pengamanan, dan Komunikasi Departemen Luar Negeri.

Joint Research Center, 2019, Understanding Our Political Nature: How to Put Knowledge and Reason at the Heart of Political Decision Making. Brussels: Europan Commission, Joint Research Center.

Kantaprawira, Rusadi. 2002. Sistem Politik Indonesia, Suatu Model Pengantar. Bandung: Sinar Baru Algensindo.

Karim, A. Gaffar. 1995. Metamorfosis, NU dan Politisasi Islam Indonesia. Yogyakarta: KLiS.

Karim, M. Rusli. 1983. Perjalanan Partai Politik di Indoneisa, Sebuah Potret Pasang Surut. Jakarta: Rajawali.

Kartodirdjo, Sartono. 1993. Pendekatan Ilmu Sosial dalam Metodologi Sejarah. Jakarta: Gramedia Pustaka Utama.

Kosim, E. 1984. Metode Sejarah, Asas dan Proses. Bandung: Fakultas Sastra Universitas Padjajaran.

1954. Kepartaian dan Parlementaria Indonesia. Jakarta: KementrianPenerangan RI. 
Maarif, Ahmad Syafii. 1996. Islam dan Politik, Teori Belah Bambu Masa Demokrasi Terpimpin (1959-1965). Jakarta: Gema Insani Press.

Mahfud MD, Mohammad. 2000. Demokrasi dan Konstitusi di Indonesia, Studi tentang Interaksi Politik dan Kebidupan Ketatanegaraan. Cetakan ke-2. Jakarta: Rineka Cipta.

Mawardi, Chalid. 1967. Practica Politika Nabdlatul Ulama: Mandajung di Tengah Gelombang. Jakarta dan Surabaya: Yayasan Pendidikan Practica.

Nasution, Adnan Buyung. 1995. Aspirasi Pemerintah Konstitusional di Indonesia: Studi Sosio-Legal Konstituante 1956-1959. Jakarta: Pustaka Utama Grafiti.

Noer, Deliar. 1987. Partai Islam di Pentas Nasional. Jakarta: Grafiti Pers.

Poesponegoro, Marwati Djoened dan Nugroho Notosusanto. 1992. Sejarah Nasional Indonesia IV. Edisi ke-7. Jakarta: Balai Pustaka.

Reiza D. Dienaputra, Surat Perintah 11 March 1966: Studi tentang Lahirnya Supersemar, 1992. Bandung: Lembaga Penelitian Universitas Padjadjaran.

Soebagijo, I.N. 1982. K.H. Masjkur, Sebuah Biografi. Jakarta: PT. Gunung Agung. Sri, Edi Swasono dan Fauzie Ridjal (Ed.). 1997. Mohammad Hatta: Demokrasi Kita Bebas Aktif dan Ekonomi Masa Depan. $2^{\text {nd }}$ Edition. Jakarta: UI Press.

Surbakti, Ramlan. 1992. Memabami Ilmu Politik. Jakarta: Grasindo.

Tim Penyusun Kamus Pusat Pembinaan dan Pengembangan Bahasa. 1996. Kamus Besar Bahasa Indonesia, Edisi II. Cetakan ke-7. Jakarta: Balai Pustaka.

van Bruinessen, Martin. 1994. NU: Tradisi, Relasi-relasi Kuasa. Pencarian Wacana Baru. Yogyakarta: LKiS.

Zuhri, Saifuddin. 1987. Berangkat dari Pesantren. Jakarta: Gunung Agung.

Zuhri, Saifuddin (Comp.). 1962. Buku Kenang-kenangan Mu'tamar XXII Partai Nabdlatul Ulama, 12-17 Tsani 1379/ 13-18 December 1959 di Jakarta. Jakarta: Yamunu.

Zuhri, Saifuddin. 1979. Sejarah Kebangkitan Islam dan Perkembangannya di Indonesia. Bandung: Al Maarif.

\section{Newspapers}

Duta Masyarakat 23 February 1959, 31 March 1959, 1 Juni 1959, 6 July 1959, 27 Januari 1960, 4, 5, 7, 9 dan 10 Januari 1961, 4 dan 28 October 1961, 20 December 1961, 21 February 1963, 2 March 1963, 20, 21 dan 22 May 1963, 13 dan 21 Januari 1965, 9 April 1965, 20 August 1965, 7 dan 9 October 1965. 